\title{
Determinants of Market Participation by Indigenous Poultry Farmers: A Case Study in Anuradhapura District in Sri Lanka
}

\author{
M.N.D.F. Abeykoon ${ }^{*}$, J. Weerahewa ${ }^{1}$ and G.L.L.P. Silva ${ }^{2}$ \\ Postgraduate Institute of Agriculture \\ University of Peradeniya \\ Peradeniya
}

\begin{abstract}
Backyard poultry farming provides multiple benefits to rural farm families in Sri Lanka. Indigenous chicken or the village chicken is the main component in backyard poultry rearing system. However, the indigenous chicken population is gradually being reduced in the country, mainly with the introduction of exotic breeds. In addition, market share of indigenous chicken is diminishing over the years. Identification of the characteristics of the farmers selling indigenous chicken and the factors that affect the market participation by indigenous chicken farmers will be useful in conservation and sustainable utilization of indigenous chicken. Hence, the objectives of this study were to identify the factors that determine poultry market participation and sales of indigenous chicken farmers. Those determinants were evaluated by using Heckman two stage econometric model. The study was carried out in Thirappane Veterinary Division (covering four selected villages) in Anuradhapura district. Data were collected by a household survey using a structured questionnaire from 104 households rearing indigenous chicken. The first step of the Heckman two stage procedure results showed that households' decision to participate in the poultry market was significantly $(p<0.05)$ affected by sex of household head and religion. The second stage estimation results revealed that the value of poultry sales was significantly $(p<0.05)$ affected by the availability of market information, the number of children below 15 years in the household, bicycle ownership, type of breeds owned and the location of households (village).Further the results suggest that, establishment of effective market information service and identification of high yielding indigenous chicken breeds will enhance the sales of indigenous chicken farmers.
\end{abstract}

Keywords: Heckman model, indigenous, market participation

\section{INTRODUCTION}

The world is facing a threat of losing genetic diversity of indigenous animals. According to the FAO's Global Data Bank, around 20\% of world's farm animal genetic resources are at risk and 62 breeds have become extinct during the last six years (FAO, 2007). Factors that cause threats to indigenous animal genetic resources include crossbreeding with and or replacement by exotic breeds, shifts in social settings, production system and market demand

\footnotetext{
Department of Agricultural Economics and Business Management, Faculty of Agriculture, University of Peradeniya, Sri Lanka.

2 Department of Animal Science, Faculty of Agriculture, University of Peradeniya, Sri Lanka

* Corresponding author: niru04307@yahoo.com
} 
for some animal products and urbanization and its impact on traditional animal agriculture (www.fangrasia.org). Effective management of farm animal genetic resources is essential to ensure global food security, sustainable development and the livelihoods of a large number of people (FAO, 2007).

Indigenous poultry production plays an important role as a source of income and food of rural farm families in Sri Lanka. This has become so important due to the valuable traits of indigenous chicken such as disease resistance, adaptation to harsh environments and ability to utilize poor quality feed. These characteristics have a high contribution in achieving sustainability in low-input production systems. However, it has been evident that the population of the indigenous livestock and poultry of Sri Lanka is gradually decreasing while some breeds/species have already been lost or is near at extinction (Punyawardena, 2010). Hence, the conservation and sustainable utilization of indigenous animals, especially chicken are required in order to fulfill the requirements in low-input production systems and enhance the livelihood of rural farmers.

Identification of the structure of the indigenous chicken rearing system and the determinants of rearing and marketing of indigenous chicken are needed in developing decision support tools and better policies for conservation and sustainable utilization of indigenous chicken. A number of studies have been conducted to analyze the determinants of rearing and marketing of indigenous animals. Study of Montshwe (2006) revealed that participation of small scale farmers in the mainstream cattle market is significantly influenced by farmer training, total herd size, access to market information, farming systems, market distance and household size.

Balagtas et al. (2007) found that adoption of cattle in Cote d'Ivoire is influenced by household characteristics, geography and the market price of fresh milk. According to their study, the likelihood of owning livestock increases with the age of the household head, ownership of television and refrigerator and market price of fresh milk. Milk sales had increase with the age of household head, family size, area of the farm land, number of cows and number of extension visits while it decreased with low salary of the livestock keeper. As described by Gebregziabher (2010) the family size, distance to the market, female headed households and education level of the household head negatively affected the market participation decision of poultry while the flock size positively affected the value of poultry sales. These studies provided evidence that socio-economic factors significantly influence the rearing and marketing of livestock.

In Sri Lanka, the role of indigenous chicken in the livelihoods of rural households has not been comprehensively investigated. It is important to understand, the characteristics of the farmer who rear indigenous chickens and the contributing factors on the poultry market participation decision and sales. Hence, Identifying the characteristics of indigenous chicken farmers, management practices, productivity of animals, socio economic determinants of poultry market participation decision and socio economic determinants of sales of indigenous chicken farmers were the objectives of this study.

\section{CONTEXT}

The agriculture sector contributes $11.2 \%$ to the GDP of the country, $24 \%$ of total export earnings and 33\% of national employment in Sri Lanka (Central Bank of Sri Lanka, 2011). Livestock is a sub sector of agriculture and accounts for $7.1 \%$ and $0.8 \%$ of the agricultural 
and national GDP, respectively (Central Bank of Sri Lanka, 2011). The most prominent subsectors of the livestock sector are dairy and poultry, which provide employment and income to a majority of rural farmers (Board of investment of Sri Lanka, 2012). In Sri Lanka, poultry rearing has been practiced for centuries as a backyard operation especially in the rural areas. The type of chicken found in backyard system is the locally adopted scavenging chicken or the village chicken. They are basically fed with kitchen refuse (coconut residues and vegetable wastes) and agricultural by products such as paddy, rice bran and broken rice and hence the cost of production is minimal (Gunarathne et al., 1993). The backyard system provides nutrients to the farm family (egg and meat) and also provides an additional income to the village economy. Despite the high expansion of commercial poultry production, backyard poultry rearing could be found in every part of the country and the most common feature in households in the Dry zone of Sri Lanka.

Meat and egg production of Village chicken is lower than the commercial chicken breeds. But there is a niche market for their meat and eggs. It is shown that village chickens in this system are with very high genetic variability (Silva, et al., 2008), and hence possesses a high potential for adaptability for any adverse conditions. Nevertheless, they show a wide variation in appearance as well as in the status of production. Naked neck, Giant, Deep brown, Orange tan, Black, Black with yellow silver, White, Light brown and White brown are some of the indigenous poultry types in Sri Lanka (Premadasa, 2004). Game type birds are also popular in some areas of the country.

Despite its nutritional and economic contribution to rural poor, village chicken production has not received enough attention for its expansion as a sustainable rural industry. No systematic study had been done so far to evaluate their production potential or the factors influencing the production status. Also no information is available on status of market facilities and their effectiveness to deliver the product to meet the high existing demand among consumers.

\section{MODEL SPECIFICATION}

\section{Theoretical model}

The subject being investigated in this study involves a two stage decision problem for the household. The first is a discrete decision of whether or not to participate in the poultry market, while the second is a continuous decision of income earned by poultry sales and conditional on a positive first decision. If unobserved preferences and characteristics affect both the discrete and continuous decisions involved, the error terms in the two respective equations are correlated. Moreover, the variables affecting the two decisions may not be exactly the same. In such situations Heckman's two-step model becomes appropriate (Heckman, 1979).

In Heckman's two step model, first the equation on the discrete decision is estimated, and second, the equation on value of poultry sales is estimated with the inverse Mill's ratio $\left(\lambda_{\mathrm{e}}\right)$ obtained from the first estimation included as an independent variable. The procedure is as follows:

Whether or not to participate in poultry market (stage 1) is modeled as:

$\mathbf{Z}=\mathbf{a X}-\mathbf{e}$

(a) 
Where $\mathbf{Z}=\mathbf{1}$ if a household participate in the poultry market, $\mathbf{Z}=\mathbf{1}$ otherwise.

Value of poultry sale equation (stage 2) is

$\mathbf{Y}=\boldsymbol{\beta} \mathbf{x}+\mathbf{u}$

Where $\mathrm{X}$ is a vector of exogenous variables, $\mathbf{Y}>\mathbf{0}$ if $\mathbf{Z}=\mathbf{1}$, and $\mathbf{Y}=\mathbf{0}$ if $\mathbf{Z}=\mathbf{0}$, $\mathrm{e}, \mathrm{u} \sim \mathrm{N}\left(0, \sigma_{\mathrm{i}}\right)$ with correlation $\rho$.

Value of poultry sale equation can be estimated as

\section{$\mathrm{E}[\mathrm{Y} / \mathrm{Z}=\mathrm{A}]=\boldsymbol{\beta} \mathbf{x}+\rho \sigma \mathrm{u} \lambda_{\mathrm{e}}+\boldsymbol{\omega}$}

Where $\lambda_{\mathrm{e}}=\varphi(\alpha \mathrm{X}) / \Phi(\alpha \mathrm{X})$, and $\varphi$ and $\Phi$ are standard normal probability density function (pdf) and cumulative distribution function (cdf), respectively of the first decision. Equation (b) is thus estimated including $\lambda_{\mathrm{e}}$ as an explanatory variable.

\section{Econometric estimation}

Heckman's two stage procedure was used to investigate the set of socio-economic variables that affect the value of poultry sales and poultry market participation decision of indigenous chicken farmers. This method was used in order to control the selectivity bias and endogenity problem and to obtain consistent and unbiased parameter estimates. Sample selection bias refers to the problems where the dependent variable is only observed for a restricted, nonrandom sample (Lin, 2007). In Heckman two stages model, sample selection bias is corrected by a probit and ordinary least squares (OLS) regression respectively, in the first and the second stage of the specification.

In Heckman procedure, sample bias is determined by the relationship between the residuals of the two stages (stage 1 and stage 2). Estimates are biased if the residuals in the stage 1 and 2 are correlated. Similarly, Stage 1 does not affect stage 2 results if the residuals are unrelated. Positive and negative correlations between residuals are indicated respectively, by positive and negative rho $(\rho)$ values. The adjusted standard error for the OLS regression equation is given by sigma $(\sigma)$. The estimated selection coefficient $(\lambda)$ or the Inverse of Mills Ratio (IMR) is given by the multiplication of rho and sigma.

The IMR is a variable for controlling bias due to sample selection (Heckman, 1979). This term is constructed using the model in the first stage and then incorporate into the model of the second stage as an independent variable. If the coefficient of the IMR is significant then the hypothesis that an unobserved selection process governs the participation equation is confirmed.

\section{Empirical specification}

Equation (a) was used to estimate the determinants of poultry market participation. Then, determinants of value of poultry sales, conditional on the participation in the poultry market, were analyzed in the second step through equation (b).

Decision to participate in the poultry market, equation (a) was specified with a number of variables included to capture the socio-economic factors of farm households that associated 
with poultry market participation. Farming experience was included and expected to be positively related with poultry market participation. Family size was expected to have a negative impact on poultry market participation. Monthly household income, Rearing other livestock (excluding chicken), Religion, Sex and Primary activity of household head were also expected to be associated with the decision to participate in poultry market, but didn't have a basis for signing the effect a priori.

The value of poultry sale regression, equation (b), was specified with a number of variables to capture household characteristics, market accessibility and chicken breeds that influence marketing of indigenous chicken. Aged household heads are believed to be good in resource use (Balagtas et al., 2008). Hence age of the household head was expected to have a positive and significant effect on poultry sales. Bicycle ownership was expected to be positively related with poultry sales. Education plays an important role in the adoption of innovations/new technologies. Therefore, education was expected to be positively associated with poultry sales. Larger family size requires larger amounts for consumption, reducing marketable surplus. Thus, the number of children in the household was expected to be inversely related to the value of poultry sales. It was expected that availability of market information significantly increases the value of poultry sales. A positive and significant relationship between the number of birds owned by the household and the value of poultry sales was expected. Poultry sales were also expected to be affected by the sex of household head, type of breeds owned and the location of households (villages).

The variables tested for the market participation and the value of poultry sales are summarized in Table 1. Equations (a) and (b) were jointly estimated using the Heckman two stage procedure in Data analysis and statistical software (STATA). 
Table 1. Description of the variables used in stage 1 and 2

\begin{tabular}{|c|c|c|}
\hline Variable name & Unit & Description \\
\hline \multicolumn{3}{|c|}{$\begin{array}{l}\text { Stage 1- Participate or not participate in poultry market } \\
l e\end{array}$} \\
\hline $\begin{array}{l}\text { Poultry market } \\
\text { participation } \\
\text { Independent variables }\end{array}$ & $\begin{array}{l}\mathrm{Yes}=1 \\
\mathrm{No}=0\end{array}$ & $\begin{array}{l}\text { Categorical variable of whether household sell } \\
\text { live birds, chicken products (meat or eggs) or no }\end{array}$ \\
\hline Sex of household head & $\begin{array}{l}\text { Male }=1 \\
\text { Female }=0\end{array}$ & $\begin{array}{l}\text { Categorical variable for whether the household } \\
\text { head is a male or female }\end{array}$ \\
\hline Farming experience & Years & Years of farming \\
\hline Religion & $\begin{array}{l}\text { Buddhist } \\
\text { Muslim } \\
\text { Christian }\end{array}$ & $\begin{array}{l}\text { Categorical variables for whether the religion is } \\
\text { Buddhist or Muslim } \\
D_{1}=1 \text { Buddhist, otherwise }=0 \\
D_{2}=1 \text { Muslims, otherwise }=0\end{array}$ \\
\hline Family size & Number & Number of people living in the house \\
\hline $\begin{array}{l}\text { Monthly household } \\
\text { income }\end{array}$ & Rupees & Monthly household income \\
\hline Primary activity & $\begin{array}{l}\text { Gvt/private } \\
\text { Business } \\
\text { Other } \\
\text { Farming }\end{array}$ & $\begin{array}{l}\text { Categorical variable for whether working on the } \\
\text { farm, Civil servant/employee in private } \\
\text { enterprise or Business person } \\
D_{1}=1 \text { Gvt/private, otherwise }=0 \\
D_{2}=1 \text { Business, otherwise }=0 \\
D_{3}=1 \text { Other, otherwise }=0\end{array}$ \\
\hline Rearing other livestock & $\begin{array}{l}\text { Yes }=1 \\
\mathrm{No}=0\end{array}$ & $\begin{array}{l}\text { Categorical variable for whether rearing other } \\
\text { livestock (cattle, buffalo, goats, pigs) or not }\end{array}$ \\
\hline
\end{tabular}




\section{Stage 2 - Value of poultry sale}

\section{Dependent variable}

Value of poultry sales

\section{Independent variables}

Sex of household head

Age of household head

Bicycle ownership

head

Number of children

Source of market

information

Number of birds owned

Type of breeds owned

Normal village chicken

Naked neck

Long leg

Village
Number

Rupees

Male $=1$

Female $=0$

Years

Yes $=1$

$\mathrm{No}=0$

Years

Number

Yes $=1$

$\mathrm{No}=0$

Yes $=1 \mathrm{No}=0$

$\mathrm{Yes}=1 \mathrm{No}=0$

$\mathrm{Yes}=1 \mathrm{No}=0$

Dematagama

Labunoruwa

Alagollawa

Ooththupitiya
Earnings by selling live birds, chicken and eggs during last 3 months

Categorical variable for whether the household head is a male or female

Age of household head in years

Categorical variable for whether the household own a bicycle or not

Number of years of schooling of household head

Household members below 15 years

Categorical variable for whether the household has any source of information on poultry market Radio, Tv, NGO, Gvt institutes etc)

Number of birds in the flock

Categorical variable for whether the household owned each breed or not

Categorical variable for the villages whether the household is located in Dematagama, Labunoruwa or Alagollawa village

\section{STUDY AREA AND DATA}

\section{Study area}

The study was carried out in Thirappane (Anuradhapura district) Veterinary Division under UNEP-GEF- ILRI FAnGR Asia project in Sri Lanka. The site is located in dry zone of the country. The annual rainfall is $1200-1900 \mathrm{~mm}$, temperature is between $28-30{ }^{\circ} \mathrm{C}$ and the elevation is $89 \mathrm{~m}$ above sea level. Irrigated and rain-fed agriculture followed by non-farm activities and livestock rearing are the main livelihood activities in the area.

\section{Sampling procedure and data collection}

Data were drawn from the households' survey conducted by the UNEP-GEF- ILRI FAnGR Asia project in Sri Lanka in Thirappane site. The survey was conducted in four selected 
villages in Thirappane site namely: Dematagama, Labunoruwa, Ooththupitiya and Alagollawa. Stratified random sampling was used where stratification was done based on the chicken rearing and thereafter households were randomly sampled within each category. The total sample size was 153 that consisted of 107 and 46 households rearing and not rearing indigenous chicken, respectively. Data were collected through a structured questionnaire.

\section{RESULTS AND DISCUSSION}

\section{Descriptive analysis}

Although, the commercial production of poultry using the specialized commercial lines is very successful and highly competitive, the backyard chicken production in rural areas still continues to contribute immensely for the livelihood of the rural poor. It could be indicated as a significant livelihood activity for many poor rural families in the study area, and for women in particular. This section provides a general overview of socio-economic factors, productivity of animals and management practices.

Table 2. Socio-economic status of poultry market participants and non-market participants

\begin{tabular}{|c|c|c|c|c|c|c|}
\hline \multirow[t]{2}{*}{ Variables } & \multirow[t]{2}{*}{ Units } & \multicolumn{2}{|c|}{$\begin{array}{c}\text { Market } \\
\text { participants } \\
(\mathrm{n}=46)\end{array}$} & \multicolumn{2}{|c|}{$\begin{array}{l}\text { Non-market } \\
\text { participants } \\
(\mathbf{n}=\mathbf{5 8})\end{array}$} & \multirow[t]{2}{*}{ t-value } \\
\hline & & Mean & SD & Mean & SD & \\
\hline Age of farmers & Years & 44.87 & 11.25 & 44.96 & 10.86 & 0.05 \\
\hline Farming experience & Years & 17.02 & 11.02 & 18.31 & 12.26 & 0.55 \\
\hline $\begin{array}{l}\text { Education level of } \mathrm{HH} \\
\text { head }\end{array}$ & Years & 7.73 & 3.69 & 7.65 & 3.73 & -0.11 \\
\hline Family size & Number & 4 & 1.13 & 4 & 1.26 & 0.84 \\
\hline Land size owned & Acres & 3.33 & 4.60 & 2.62 & 1.94 & -1.06 \\
\hline
\end{tabular}

Data source: FAnGR project, household survey data 2010

Note: Two sample $t$ tests for comparison of poultry market participants and non participants do not reveal any significance

The average age of both poultry market participants and non-market participants was 45 years (Table 2). The average farming experience of market participants and non-market participants were 17 and 18 years, respectively. In both groups, the average education level of household head was approximately 8 years. The average family size was 4 in both groups. The average land size owned by poultry market participants and non market participants were 3.3 acres and 2.6 acres, respectively. However, no statistical differences were noticed between poultry market participants and non participants with respect to the variables given in Table 2 .

Some of the productivity parameters of indigenous chicken in the studied area are given in Table 3. 
Table 3. Productivity of indigenous chicken in the study area

\begin{tabular}{llcc}
\hline Variables & Units & Mean & SD \\
\hline Age at first laying & Months & 5.78 & 2.48 \\
No. eggs / clutch & Eggs & 18 & 8.89 \\
No. clutch / year & Number & 3.33 & 2.28 \\
Male weight at maturity & $\mathrm{kg}$ & 1.77 & 0.71 \\
Female weight at maturity & $\mathrm{kg}$ & 1.30 & 0.54 \\
\hline
\end{tabular}

Data source: FAnGR project, household survey data 2010

Note: Production performance of Normal village chicken ecotype are presented

The average age of pullets at first laying was 5.78 months. The average number of eggs/clutch was 18 with an average 3 clutch/year. The average weight of adult male and female normal village chicken were $1.77 \mathrm{~kg}$ and $1.30 \mathrm{~kg}$, respectively. These results showed that the production performance of indigenous chicken were comparatively low. However, Aberre (2000) revealed that despite the low productivity, indigenous chicken possess desirable characteristics such as thermo-tolerance, resistance to some diseases, good egg and meat flavor, presence of hard egg shells, high fertility and hatchability as well as high dressing percentage. Therefore, the indigenous chicken has the potential to improve in a rural setting while enhancing the livelihood of rural farm families.

Some of the management practices of indigenous chicken farmers in the study area are given in Table 4.

Table 4. Chicken management practices of study area

\begin{tabular}{llc}
\hline Variables & & \% Households \\
\hline Housing practices & Free range & \\
Day & Confined (no roof) & 96.3 \\
& Confined (with roof) & - \\
\multirow{2}{*}{ Night } & Free range & 3.7 \\
& Confined (no roof) & 11.1 \\
& Confined (with roof) & 1.2 \\
& & 87.6 \\
Feeding practices & Kitchen waste & 32.3 \\
& Grains & 14.0 \\
Breeding practices & & \\
& Natural uncontrolled & 95 \\
\hline
\end{tabular}

Data source: FAnGR project, household survey data 2010

Note: Management practices of Normal village chicken ecotype are presented

Indigenous chicken production is characterized by low input production systems (Alemu, 1995). The results in Table 4 indicated that the majority of indigenous chicken farmers used free range system during the day time (over 96.3\%) and confined chicken at night (87.6\%). There was no purposeful practice of feeding chicken while scavenging was the predominant way of feeding. In addition to scavenging, supplementary feeds (kitchen waste-32.3\%, grains-14\%) were provided to chicken when available. The majority $(95 \%)$ of indigenous chicken farmers used natural uncontrolled breeding for their chicken and no systemic 


\section{Stage 2- Value of poultry sale}

breeding programs were practiced. The study further revealed that minimum health care practices were followed by the indigenous chicken farmers. Hence, the cost of medicine for indigenous chicken was negligible. In overall, the results proved that the majority of indigenous chicken farmers use traditional management practices which lead to low input production systems.

\section{Econometric analysis}

Results of the stage 1 (probit) and stage 2 (OLS regression) are given in Table 5. The probability value indicates that the model as a whole is statistically significant at $1 \%$ level of significance.

Table 5. Heckman's two stage model estimation results and marginal effects

\begin{tabular}{lccc}
\hline \multicolumn{1}{c}{ Variable name } & Coefficient & p-value & Marginal effect (\%) \\
\hline $\begin{array}{l}\text { Stage 1-Poutlry market participation } \\
\text { Constant }\end{array}$ & 0.035 & 0.968 & \\
Sex of household head & 0.797 & $0.096^{*}$ & 31.4 \\
Farming experience & -0.010 & 0.388 & -0.40 \\
Religion & & & \\
Buddhist & -1.137 & $0.013^{* *}$ & -38.8 \\
Muslim & -0.741 & $0.058^{*}$ & -28.7 \\
Family size & -0.007 & 0.948 & -0.28 \\
Monthly household income & 0.001 & 0.108 & 0.04 \\
Rearing other livestock & -0.522 & 0.111 & -20.25 \\
Primary activity & & & \\
Gvt / private enterprise & -0.608 & 0.301 & -21.98 \\
Business & -0.579 & 0.219 & -21.24 \\
Other & -0.454 & 0.203 & -17.25 \\
& & &
\end{tabular}




\section{Constant}

Age of household head

Sex of household head

Level of education

Bicycle ownership

Number of children

( $<15$ years old)

Source of information

Number of animals owned

Breed type owned

Normal village chicken

Naked neck

Long legs

Village

Dematagama

Alagollawa

Labunoruwa

$\operatorname{Lambda}(\lambda)$

$\operatorname{Rho}(\rho)$

$\operatorname{Sigma}(\sigma)$

Chi-square

$\mathrm{P}$-value

Number of observation
$-1649.77$

0.228

2.853

0.860

$-13.012$

0.983

19.213

0.683

653.085

0.056 *

$-358.435$

$0.024 * *$

381.495

$0.004 * * *$

6.976

0.734

137.516

0.772

737.716

0.045 **

444.767

0.332

962.434

$0.098^{*}$

1106.936

$0.086^{*}$

418.076

0.447

1215.42

0.946

1283.86

31.19

0.005

104

$* * *, * *$ and $*$ indicate statistically significant at 1,5 and $10 \%$, respectively

Dependent variable: Poultry market participation (probit) and value of poultry sales (OLS)

The results confirmed that the decision of a household to participate in poultry market is influenced by sex of the household head and religion. The analysis on variable religion showed that, being a Buddhist and being a Muslim reduced the probability to participate in poultry market by $38.8 \%$ and $28.7 \%$, respectively compared to being a Christian. Hence, there is an association between the decision to participate in poultry market and the cultural background of the household, for instance the religion. Male-headed households showed more probability to participate in poultry market compared to female-headed households. Marginal effect indicated that, being a male-headed household increases the probability of poultry market participation by $31.4 \%$ compare to being a female-headed household. This result is consistent with the findings of Gebregziabher (2010) that the probability to participate in poultry market decrease with female household headship. According to the first stage results of Heckman two stage model, farming experience, family size, rearing other livestock, primary activity and monthly household income do not significantly influence the poultry market participation by indigenous chicken farmers.

Age of the household head, sex, level of education, bicycle ownership, number of children in the household, availability of market information sources, the number of animals owned, the types of breeds owned and the village where the household is located were the variables tested as influencing the value of poultry sales. Among the tested variables, number of 
children, availability of market information sources, bicycle ownership, the types of breeds owned and the household location were statistically significant with expected signs. The number of children in the household has a negative relationship with the value of poultry sales. The result showed that the increase in the number of children in the household by one, causes 358.43 rupees decrease in the value of poultry sales. This can be due to the fact that larger family size (with more children) requires a larger amount for consumption, reducing marketable surplus. Singh and Rai (1998) observed a similar effect in marketing of buffalo milk in Harayana. Availability of market information was positively related to the value of poultry sales by increasing the value of poultry sale by 381.49 rupees. This indicates that good understanding on the market fluctuations invariably increase the poultry sales where a farmer can earn a higher income by selling chicken at a good price.

The bicycle ownership was positively associated with the value of poultry sales. Quantification of the association revealed that owning a bicycle causes the value of poultry sales to rise by 653.08 rupees. The reason might be the low transportation cost. This finding is consistent with the finding of Olwande and Mathenge (2010) that ownership of transport equipment was significantly associated with the agriculture market participation among poor rural households in Kenya. Normal village chicken, Naked neck and Long legs chicken were the predominant indigenous breeds/ecotypes under backyard poultry rearing system in the study area. The results revealed that the value of poultry sale was higher with owning Naked neck chicken breed than owning other two breeds. The reason may be the production and quality of meat is higher with Naked neck chicken breed than the other breeds. Further, owning Naked neck chicken increased the value of poultry sale by 737.71 rupees. The location of the household (the village) influences the value of poultry sales. The results showed that the value of poultry sale was higher by 962.43 and 1106.93 rupees of farmers in Dematagama and Alagollawa villages respectively, compared to farmers in Ooththupitiya village. High market accessibility might be the reason for more sales in those two villages.

According to the model output, the Lambda (IMR) or selectivity bias correction factor was positive, but had a statistically insignificant impact on value of poultry sale. This result suggests that there appears to be no unobserved factors that might affect both probability of market participation and value of poultry sales by indigenous chicken farmers.

\section{CONCLUSIONS}

The backyard chicken production could be indicated as a significant livelihood activity for many poor rural families in the area of study. Traditional management practices were predominant while the productivity of animals is comparatively low. Hence, the prevailing indigenous chicken production system in the study area could be categorized under low-input low-output production system.

The results of Heckman two stages procedure revealed that the religion and sex of the household head stimulate the poultry market participation decision (stage 1) while the number of children below 15 years, availability of market information, bicycle ownership, the types of breeds owned and the location of the household (village) drive the value of poultry sale of indigenous chicken farmers (stage 2). Further, Buddhists and Muslims have a lower probability to participate in the poultry market than Christians. Also, male-headed households have a greater probability in poultry market participation than female-headed households. According to the results of the second stage, a positive association of value of poultry sales with the bicycle ownership and the availability of market information were 
observed whereas the association of value of poultry sale was negative with the number of children. Moreover owning Naked neck chicken breed enhances the poultry sales more than owning normal village chicken and long leg chicken breeds. Further, value of poultry sales was influenced positively by Dematagama and Alagollawa villages compared to Ooththupitiya village.

Findings of the study suggest that, competitive market and market information services have to be established and strengthened in order to improve the value of poultry sale. Moreover, identification and characterization of indigenous chicken breeds is required to select high yielding breeds with good market value (e.g. Naked neck breed). Attention should be paid to improve the market accessibility for indigenous chicken in the study area.

\section{ACKNOWLEDGEMENT}

Ms. Abeykoon is a graduate student attached to GEF-UNEP-ILRI FAnGR Asia project which is implemented in Sri Lanka by University of Peradeniya. The Global Environment Facility (GEF) is supporting the Development and Application of Decision-support tools to conserve and sustainably use genetic diversity in indigenous livestock and wild relatives project initiative led by Bangladesh, Pakistan, Sri Lanka, Vietnam. International Livestock Research Institute (ILRI) is coordinating the project with implementation support from the United Nations Environment Programme (UNEP). Working in the four partner countries the project addresses ways to secure and improve livelihoods of poor livestock keepers through utilization and conservation of indigenous FAnGR and their wild relatives. The authors acknowledge the support of ILRI project team, particularly Prof. M.N.M.Ibrahim, Dr. Okeyo Mwai, Dr. Isabelle Baltenweck, Dr. Jane Poole, Dr. R.C. Bett, Ms. Eunice Kariuki and all members of Sri Lankan project team.

\section{REFERENCES}

Aberre, M. (2000). Comparative studies on performance and physiological responses of Ethiopian indigenous ('Angete-melata') chicken and their F1 crosses to long term heat stress.PhD thesis. Martin-Luther University, Halle-Wittenberg, Berlin, Germany. pp.182.

Alemu, Y. (1995). Poultry production in Ethiopia. World's Poultry Science Journal.51,197201.

Balagtas, J.V., Coulibaly, J.Y., Jabbar, M. and Negassa, A.( 2007). Dairy Market Participation with Endogenous Livestock Ownership: Evidence from Cote d'Ivoire [on line].[Accessed on 29.06.2010].Available at http://www.ideas.repec.org/p/ags/aaea07/9728.html.

Barry, B.M. (2005). Determinants of urban livestock adoption in the zone dense' of khorogo, Cote d'Ivore: A Tobit Approach [online]. [Accessed on 21.03.2012]. Available at http://web.idrc.ca/en/ev-84289-201-1-DO_TOPIC.html.

Board of Investment of Sri Lanka. (2012). Key sectors for investment- Agriculture [online]. [Accessed on 25.06.2011]. Available at www.investsrilanka.com. 
Bonsu, A.M., Marfo, D.S., Birol, E. and Roy, D. (2010). Investigating the role of poultry and the impact of HPAI on livelihoods in Ghana, Africa/Indonesia team working paper no.35

Central Bank of Sri Lanka. (2010).The annual report. Central Bank of Sri Lanka. Colombo, Sri Lanka

FAnGR-Asia. Development and application of decision support tools to conserve and sustainably use genetic diversity in indigenous livestock \& wild relatives [online]. [Accessed on19.02.2012]. Available at www.fangrasia.org.

FAO.(2007). International technical conference on animal genetic resources for food and agriculture: Switzerland.

Gebregziabher, D.(2010).Market chain analysis of poultry: The case of Alamata and AtsbiWonberta Woredas of Tigray region[on line].[Accessed on 30.06.2010].Available at www.ipmsethiopia.org/content/.../FinalTHesis\%20_DawitGebregziabher.pdf

Gunarathne S.P., Chandrasiri A.D.N., Mangalika W.A.P. and Roberts J.A. (1993). Feed resource base for scavenging village chickens in Sri Lanka. Tropical animal Health \& production. 25(4), 249-257.

Heckman, J.(1979). Sample selection bias as a specification error. Econometrica 47: 153161.

Lin, W.(2007).Model with self-selection [on line].[Accessed on 27.06.2010].Available at http://www.wanchuanlin.org/.../Lecture3typed.pdf

Montshwe, B.D., Jooste, A. and Alemu, Z.G. (2006). Factors affecting participation in mainstream cattle markets by small scale cattle farmers in South Africa[on line].[Accessed on 28.6.2010]. Available at http://www.etd.uovs.ac.za/ETD-db/theses/available/etd02022007.../MontshweBD.pdf

Olwande, J. and Mathenge, M. (2010). Market participation among poor rural households in Kenya. Tegemeo Institute, Egerton University, Nairobi.

Premadasa, K.M.G.P. (2004). Phenotypic variation of village chicken in Sri Lanka: Development of an interactive CD ROM. Research report submitted in partial fulfillment of the requirement of the degree B.Sc. Agriculture. Faculty of Agriculture, University of Peradeniya.

Punyawardena, B. V. R. (2010). Agro-ecological context and Farm Animal Genetic Resources (FAnGR) in Sri Lanka, In: Indigenous Animal Genetic Resources in Sri Lanka status potentials and opportunities (Eds. Pradeepa Silva). FAnGR Asia project, Sri Lanka.

Ramlah, A.H. (1999). Production aspects of village chicken in the South-East Asian region. In: The Scope and Effect of Family Poultry research and Development. Lead paper 5 in the 1st INFPD/FAO Electronic Conference on Family Poultry (1999) [on line]. [Accesseed on 26.06.2010].Available at (http://www.fao.org/ag/againfo/subjects/en/infpd/documents/econf_scope/paper5.html. 
Silva P. (ed) (2010). Indigenous Animal Genetic Resources in Sri Lanka: Status, Potential and Opportunities. UNEP- GEF- ILRI FAnGR Asia project, University of Peradeniya, Sri Lanka.

Silva P, Guan X, Ho-shing O, Jones J, Xu J, Hui D, Notter D and Smith E. (2008). Mitochondrial DNA-based analysis of genetic variation and relatedness among Sri Lankan indigenous chickens and the Ceylon Jungle Fowl (Gallus lafayetti). Animal Genetics. Doi:10.1111/j.1365-2052.2008.01783.x.

Singh, V. and Rai, K.N. (1998). Economics of production and marketing of buffalo milk in Harayana. Indian J. of Agric. Economics. 53(1), 43-52.

Weersink, A., Nicholson, C., Weerahewa, J. (1997).Multiple job holdings among dairy farm families in New York and Ontario. Agricultural Economics 18, 127-143. 